\title{
THE INFLUENCE OF BABY GYMNASTICS ON BABY DEVELOPMENT AGES 6-9 MONTHS
}

\author{
Siti Patimah ${ }^{1)}$ Tavazuli Clara ${ }^{2)}$ Herni Kurnia ${ }^{3)}$ \\ Email : spatimah1220@gmail.com
}

\begin{abstract}
Background: The future of a nation depends on the success of children in achieving optimal growth and development. Good and sufficient nutrition, good health status, proper parenting, and proper stimulation will help children to develop optimally. Efforts to stimulate children's development, including by doing gymnastics in infancy. Proper stimulation will stimulate the brain so that the development of movement, speech and language, social and independence abilities takes place optimally according to age. This study aims to analyze the effect of the application of baby gymnastics on the development of infants aged 6-9 months in the Panglayungan Public Health Center, Tasikmalaya City..

Methods: This study used a quasi-experimental method and pre-post test only group design. The number of samples was 19 people. Each respondent was screened for development before and after being given baby gymnastics treatment for 1 month.

Results:The description of the development of infants aged 6-9 months in the work area of the Panglayungan Health Center, Tasikmalaya City before stimulation with baby gymnastics had an appropriate development of $73.7 \%$ and $26.3 \%$ doubtful. After stimulation with baby gymnastics, $100 \%$ of babies reach development according to their age, showed by the $p$ value 0,000 .

Conclusion: Based on the results of the study, it was found that there was an effect of baby gymnastics on the development of infants aged 6-9 months
\end{abstract}

Keyword : Development; Stimulation; Baby Gymnastics

1,2,3 Department of Midwifery, Poltekkes Kemenkes Tasikmalaya, Indonesia Jalan Cilolohan No. 35 Kota Tasikmalaya Jawa Barat 46115, Indonesia

Received: March 24, 2021; Revised: August 24, 2021; Accepted: September 28, 2021

Background. The first year of life (the period from the fetus in the womb until the child is 2 years old) is a very important period in the growth and development of children.In Indonesia in 2015 there were 4,462,562 babies recorded from $23,009,874$ children under five (BPS, 2015).In 2016 the number of live births in West Java Province was 845,964 babies, and in Tasikmalaya City there were 1,201 babies (Dinkes, 2017).

The high birth rate is expected to be accompanied by the maximum quality of the nation's next generation. Monitoring the growth and development of children is very important to detect early growth and development disorders. Permenkes RI No. 66 (Kemenkes RI, 2014) concerning monitoring of children's growth, development, and growth and development disorders stipulates article 3 paragraph (3) that monitoring of children's growth, development and developmental disorders is directed to improve health and nutritional status, cognitive, mental, and child psychosocial. Article 6 paragraph 1 states that monitoring of children's growth, development and developmental disorders must be carried out in a comprehensive and quality manner through adequate stimulation activities, early detection, and early intervention of children's growth and development disorders.

As a candidate for the nation's next generation, the quality of children's growth and development in Indonesia needs serious attention. Children must receive good nutrition, adequate stimulation and affordable quality health services, including early detection and intervention of growth and development deviations so that they can grow and develop optimally according to their genetic potential and be able to compete in the global era (Depkes RI, 2016).

One of the screenings that can be done to detect developmental disorders is to use the Stimulation, Detection, and Early 
Developmental Intervention (SDIDTK) guidelines. Families play an important role to help provide stimulation or stimulate children's development optimally and thoroughly.

Stimulation is defined as stimulation that comes from the external environment, including exercise and play. One form of stimulation using exercise is infant exercise, including the application of the baby gymnastics method.

Baby Gymnastics is one method that can be a stimulation aimed at optimizing the process of growth and development (Kusyairi, 2008). Stimulation in the form of gymnastics is one of the efforts to optimize baby's motor growth and development. Giving stimulation can be in the form of exercise therapy which is a form of exercise to improve and optimize better conditions and will provide stimulation to the body on an ongoing basis

Methods. This type of research is a quantitative research with a quasi-experimental approach and a pre-post test only group design.The location of this research was the work area of the Panglayungan Health Center, Tasikmalaya City in the period November December 2018. The population in this study was all babies aged 6-9 months. Sampling used purposive sampling technique. With inclusion and exclusion criteria as follows:

Inclusion criteria:

a. Infants aged 6-9 months whose birth weight was between 2,500-4,000 grams.

b. Infants aged 6-9 months who were given breast milk and Breast Milk Substitute (PASI).

C. Infants aged 6-9 months who were the 1st, 2nd, or 3rd child.

Exclusion criteria:

a. Infants aged 6-9 months who were sick.

b. Drop out to be a research sample.

Based on the calculation results, the sample in this study amounted to 19 infants. Data collection was carried out by direct observation and treatment by researchers together with enumerators who had the same competence by using a checklist and Growth Pre Screening Questionnare (KPSP) format. Baby gymnastics treatment was carried out for 1 month every day in the morning or evening with a duration of 5-10 minutes. The data were normally distributed so that to see the relationship between variables, bivariate analysis was carried out using the T-test.
Result and Discussion. The results of the study obtained an overview of the development of infants aged 6-9 months in the work area of the Panglayungan Health Center, Tasikmalaya City before and after stimulation with baby gymnastics can be seen in the table below:

1. Univariate analysis

Table 1. Frequency distribution of the developmental picture of infants aged 6-9 months before and after stimulation with baby gymnastics

\begin{tabular}{|c|c|c|c|c|}
\hline \multirow{3}{*}{ Category } & \multicolumn{4}{|c|}{$\begin{array}{c}\text { Baby Development Age 6-9 } \\
\text { months }\end{array}$} \\
\hline & $\begin{array}{l}\text { Bef } \\
\text { Gy }\end{array}$ & $\begin{array}{l}\text { Baby } \\
\text { astic }\end{array}$ & $\begin{array}{l}\text { Aft } \\
\text { Gy }\end{array}$ & $\begin{array}{l}\text { Baby } \\
\text { astic }\end{array}$ \\
\hline & $f$ & $\%$ & $f$ & $\%$ \\
\hline Deviation & 0 & 0 & 0 & 0 \\
\hline Doubtful & 5 & 26,3 & 0 & 0 \\
\hline In Accordance & 14 & 73,7 & 10 & 100 \\
\hline Amount & 19 & 100 & 19 & 100 \\
\hline
\end{tabular}

Table 1 shows that the description of the development of infants aged 6-9 months in the work area of the Panglayungan Health Center, Tasikmalaya City before stimulation with baby gymnastics mostly had appropriate development, namely 14 people $(73.7 \%)$ and doubting as many as 5 people (26.3\%). After doing baby gymnastics there was a change, namely 19 people (100\%) had appropriate development

2. Bivariate Analysis

Based on the results of the study, it was found that the effect of baby gymnastics on the development of infants aged 6-9 months in the Panglayungan Community Health Center, Tasikmalaya City by used the t-test in the table below:

Table 2 The effect of baby gymnastics on the development of babies aged 6-9 months

\begin{tabular}{llll}
\multicolumn{1}{c}{ Description } & $\begin{array}{l}\text { Progression } \\
\text { Average }\end{array}$ & Increase & $\begin{array}{c}P \\
\text { Value }\end{array}$ \\
\hline $\begin{array}{l}\text { After baby gym } \\
\text { Before baby } \\
\text { exercise }\end{array}$ & 10 & 1.105 & 0,000 \\
\hline
\end{tabular}

Based on table 2, the above figures can be interpreted $\rho_{\text {value }}$ worth 0.000 . Because the value of 0.000 is smaller than $<0.05$, it can be concluded that there are developmental changes in infants before and after baby gymnastics is carried out, so it can also be concluded that "there is an effect of baby gymnastics on the development of infants aged 
6-9 months in the work area of Panglayungan Health Center, Tasikmalaya City".

Based on the description above, it was found that the description of the development of infants aged 6-9 months in the work area of the Panglayungan Health Center, Tasikmalaya City before stimulation with baby gymnastics mostly had appropriate development, namely 14 people $(73.7 \%)$ and doubting as many as 5 people (26.3\%). Meanwhile, after the baby gymnastics was carried out, there were changes, namely 19 people (100\%) had appropriate development.

The findings at the research site before the baby gymnastics were carried out were babies who were still in a dubious condition at the time of the study, including not being able to pick up small objects around them, picking up toys out of reach of the baby, lifting the chest with both arms as a support, and not picking up toys. can lift his neck upright.

Baby gymnastics can be a stimulus for those who are still doubtful in the KPSP assessment. A 6-month-old baby who is still unable to hold his neck rigidly when held in both hands and pulled can be stimulated through baby gymnastics. Babies who have not been able to lift the chest with both arms as support can be stimulated by holding the baby's upper body using both hands, and placing the thumbs on his back between the shoulder blades.Position in such a way that the baby's upper arms are straight and are used to support the baby's upper body.

When a 9 month old baby is stimulated and still can't try to stand up using a pedestal on both legs, it can be trained with baby gymnastics through coordinated movements of the legs. The baby can be positioned on his right side or in a supine position. If the baby is supine, hold the baby's lower leg, bend the baby's leg, point the opposite hand so that the hands and feet touch, this movement is done 5-8 times.

Positioning the baby on his stomach, by holding the baby's lower legs in the calf area with the thumb on the front and the other four fingers on the back. Lift the baby's right lower leg up with the stomach still attached to the base. Lift the baby's right and left legs, pointing them across so that the soles of the feet can touch. This can trigger the movement of the leg muscles so that it trains for movement and preparation for support when the baby learns to stand.
Babies who have not been able to reach toys/objects around them can be stimulated by strengthening the baby's upper muscles so that they are able to reach objects/toys around them by involving the upper muscles. Soetjiningsih (2010) explains that development is the result of a process of maturity and learning. Maturity is an intrinsic process that occurs by itself, according to the potential that exists in the individual. Learning is a development that comes from practice and effort. Through learning, children gain the ability to use inherited resources and their potential.

The benefits of baby gymnastics according to Swandari (2015) are that it can bring the relationship between parents and children closer, train the baby's muscle strength and endurance to be more elastic in preparing for the development of further movements, train coordination and reaction skills as well as joint stability, teach children to interact with the environment, and can also monitor the development and recognize the muscles of the bones and various variations of movement.

Ridho (2015) obtained the results of research from 6 babies in the treatment group after being given baby gymnastics for 1 month, it was found that 2 babies with the ability to crawl at the belly crawl stage, 1 baby at the crab crawl stage, 2 babies with the leapfrog crawl ability and 1 baby was able to reach the classic stage. crawl, while as many as 5 babies in the control group at the belly crawl stage. So it can be concluded that there is an effect of giving modern baby gymnastics to infants aged 16-24 weeks on the ability to crawl.

In contrast to other studies, the results of Fildzah's research (2017) at Integrated Healthcare Center (Posyandu) Modinan Yogyakarta found that there was no difference in the effect of baby gymnastics with baby massage in improving gross motor skills in children aged 3-12 months.

The results of Purwanti's research (2016) found that babies who did baby gymnastics with normal development were $81.3 \%$ while babies who did baby gymnastics with suspicious development were $18.8 \%$. The results of the chi square statistical test obtained $p$-value results of $0.42(p=<0.05)$, which means that there is a relationship between the implementation of infant gymnastics and infant development. 
In line with the results of this study, L Khoir's research (2019) which used a pre and post test one group design conducted a study for 4 weeks with a frequency of 2 times in 1 week getting the Wilcoxon test results $p=0.01$ $(p=0.05)$. which means that there is an effect of the baby gym on gross motoric development of children aged 3-12 months at the Uswatun Hasanah Integrated Healthcare Center (Posyandu)

Based on the description above, it can be harmonized with the results of research that development before baby gymnastics will be able to give a good effect on babies who are still doubtful to be able to improve development.

Conclusion and Suggestions. Based on the results of research and discussion, the authors conclude as follows The description of the development of infants aged 6-9 months in the work area of the Panglayungan Health Center, Tasikmalaya City before stimulation with baby gymnastics had an appropriate development of $73.7 \%$ and $26.3 \%$ doubtful. After stimulation with baby gymnastics, $100 \%$ of babies reach development according to their age. There is an effect of baby gymnastics on the development of infants aged 6-9 months in the Panglayungan Community Health Center, Tasikmalaya City. It is recommended for mothers who have toddlers to provide baby exercise stimulation in order to optimize the development of babies aged 6-9 months

Acknowledgements Thank you to all who have helped the completion of this research, especially the research Department of Midwifery, Poltekkes Kemenkes Tasikmalaya
References.

Dinkes Kota Tasikmalaya. (2017). Laporan Tahunan DKK Kota Tasikmalaya

Fildzah (2017). Perbedaan pengaruh senam bayi dengan pijat bayi dalam meningkatkan motoric kasar pada usia 312 bulan di Posyandu modinan Yogyakarta.core.ac.uk

Depkes RI (2016). Pedoman Pelayanan Stimulasi Deteksi Dan Intervensi Dini Tumbuh Kembang Anak di Tingkat Pelayanan Dasar. Jakarta : Departemen Kesehatan Indonesia

Kemenkes RI (2014) Permenkes No.66 Tahun 2014 tentang Pemantauan Pertumbuhan, Perkembangan, dan Gangguan Tumbuh Kembang Anak Purwanti, (2016). Efektifitas pelaksanaan senam bayi Terhadap Peningkatan Perkembangan Bayi.

Kusyairi. (2008). Panduan Senam Bayi. Jakarta: Puspa Swara

L Khoir (2019). Pengaruh Baby Gym Terhadap Perkembangan.....diakses dari digilib2.unisayogya.ac.id

Purwanti, (2016). Efektifitas pelaksanaan senam bayi Terhadap Peningkatan Perkembangan Bayi.

Ridho, (2015) Pengaruh Pemberian senam bayi modern pada bayi umur 16-24 minggu terhadap kemampuan merangkak. Eprint.ums.ac.id

Soetjiningsih. (2010) . Tumbuh Kembang Anak. Edisi ke-2. Jakarta. Penerbit Buku Kedokteran EGC

Swandari, A (2015). Pengaruh senam bayi terhadap Kecepatan kemampuan Motorik kasar pada bayi usia 5 bulan. Jurnal insan Cendekia Vol.1 No.2 Mei 2015 